\title{
Bio-economy in Greece: Current trends and the road ahead
}

\author{
Electra Papadopoulou ${ }^{1}$, Konstantinos Vaitsas ${ }^{2}$, Ioannis Fallas ${ }^{3}$, Giorgos Tsipas ${ }^{4}$, Konstantinos Chrissafis ${ }^{5}$, \\ Dimitrios Bikiaris ${ }^{6}$, Constantina Kottaridi ${ }^{7}$ and Konstantinos E. Vorgias ${ }^{7,8^{*}}$
}

\begin{abstract}
Economic activity that takes environmental protection into account and uses the environmental benefits of an area or country may continuously combine growth with sustainability thereby providing prosperity and societal quality. This paper aims to complement European research on Bioeconomy by reviewing current situation and future trends in Greece. Current data testify that there are significant opportunities for Greece to progress towards a lucrative economy based on renewable resources. The effective growth of such Bioeconomy in Greece depends on the successful cooperation of all stakeholders (state, business, citizens). This is the first study that provides a numerical analysis of the Bio-economy opportunities for Greece and may constitute the foundation for future research, suggestions for policy measures and strategic planning.
\end{abstract}

Keywords: Greek Bio-economy, initiatives, education, strategy, trends

'CHIMAR HELLAS SA, Sofouli 88, 55131 Kalamaria, Thessaloniki, Greece

${ }^{2}$ Innovation expert, Member of the States Representatives Group of the Bio-based Industries Joint Undertaking (SRG BBI)

${ }^{3}$ Bio-energy and Environment Cluster, Western Macedonia, Region of Western Macedonia premises

${ }^{4}$ Law, Regulation and Management, International Hellenic University, 57001, Thessaloniki, Greece

${ }^{5}$ Solid State Physics Section, Physics Department, Aristotle University of Thessaloniki, 54124 Thessaloniki, Greece

${ }^{6}$ Department of Chemistry, Aristotle University of Thessaloniki, 54124 Thessaloniki, Greece,

${ }^{7}$ Bio-economy and Sustainable Growth Laboratory, Department of Economics, University of Pireaus University, Karaoli and Dimitriou 80, 18534 Pireaus, Greece

${ }^{8}$ Department of Biology, Section of Biochemistry and Molecular Biology, National and Kapodistrian University of Athens, 15701 Zografou, Greece

*Corresponding author: K. E. Vorgias

E-mail:cvorgias@biol.uoa.gr

DOI: 10.2478/ebtj-2018-0018
C 2018 Authors. This work was licensed under the Creative Commons Attribution-NonCommercialNoDerivs 3.0 License.

\section{Introduction}

In the relatively short time we have been walking the Earth, humans have left an indelible impact on the planet. Scientists unanimously agree nowadays that our actions have altered the Earth's natural processes enough, to enter a new geological epoch, called the Anthropocene. Anthropocene defines Earth's most recent geologic time period as being human-influenced. It is based on overwhelming global evidence, that atmospheric, geologic, hydrologic, biospheric and other earth system processes are now altered by humans. Fossil-fuels are biomass stored in geological form. They constitute the accumulated energy of 500 million years of photosynthesis. This sounds reassuring, but it is not, since we have consumed 50 - 150 million years of stored sunshine between 1950 and 2010, according to McNeill \& Engelke, 2013 (1).

Earth's population is expected to exceed 9 billion by 2050. Nowadays, people are called to face three major challenges relative to our planet: (a) reducing dependence on fossil fuels; (b) mitigating the effects of climate change; and (c) achieving a sustainable, adequate and safe food chain. (2) The UN responded to these challenges by launching the 17 Millennium Goals or Global Goals for Sustainable Development (GGSD) in a global summit that took place in 2015 (3). The European Union with the $5^{\text {th }}$ Research and Innovation Framework Programme (1998 - 2002) and the parallel development of a Strategy on Biotechnology, provided a solid foundation for the development of the so-called Knowledge-Based Bio-Economy (KBBE) (4). A few years earlier, prior to the launch of the $7^{\text {th }}$ Framework Programme (2007-2013) the KBBE concept emerged. The accumulated experience and new societal expectations triggered the EU to launch a Strategy on Bio-economy on 2012. The Bio-economy was born, yet no clear and uniform definition for it is available.

This paper aims to complement European research on bioeocnomy by describing current trends and the situation in Greece. This is the first study that provides a numerical 
analysis of the Bio-economy in Greece and may constitute the foundation for future research providing suggestions for policy measures and strategic planning. The next section describes the Bio-economy concept and prospects. Section 3 describes current situation in terms of policy agents involved in Bio-economy as well as actions undertaken so far. Finally, section 4 provides concluding remarks.

\section{Bioeconomy prospects Bioeonomy concepts}

To date, Bio-economy has been given several definitions. According to the European Commission's approach, it encompasses the "production of renewable biological resources and the conversion of these resources and waste streams into value-added products, such as food, feed, bio-based products and bioenergy" $(4,5)$.

The OECD defines Bio-economy as the "transformation of life science knowledge into new, sustainable, eco-efficient and competitive products" (6), while the Communiqué of the GBS2015 defines it as "the knowledge-based production and utilization of biological resources, innovative biological processes and principles to sustainably provide goods and services across all economic sectors" $(6,7,8,9)$.

The cornerstone of Bio-economy, the sustainability, revolves around efficient exploitation of biomass; a renewable organic carbon source that includes all biological materials on land and sea (plants, trees, animals, fish and microbes). Biomass resources include primary (taken directly from the resource), secondary (resulting from the processing of primary biomass resources) and tertiary sources of biomass (post-consumer residue streams including animal fats and greases, used vegetable oils, packaging wastes, and construction and demolition debris) (10).

Evidently, the Bio-economy calls for research and innovation to sustainably produce renewable raw materials in agriculture, forestry, fisheries and aquaculture and to process renewable raw materials into value added products in food, bio-based and energy industries. The Knowledge-based Bio-economy (KBBE) was initiated in 2005; it describes knowledge base advances in Life Sciences and Biotechnologies along with other technologies such as nanotechnologies, chemistry, information technologies etc. In other words, the KBBE may be defined as "life sciences and biotechnology knowledge converging with other technologies to transform into new, sustainable, eco-efficient and competitive products" (10).

The term Bio-economy includes all industries and economic sectors that produce, manage or otherwise use biological resources including bio-waste. Biological resources lie at the heart of Bio-economy and represent 4 unique features: (a) renewability; (b) carbon-friendliness or carbon-neutrality; (c) strong potential for efficient re- and multi-use degradability and recyclability, i.e., waste management and (d) new functions/properties of their products, like longer lifetime, higher durability and stability, lower or zero emissions, less or no toxicity and non-flammability, among others.
Concepts like Circular Economy, Bio-based Economy, Green Economy, biomass biorefinery, zero waste economy and sustainable development are directly related to Bio-economy. The Circular Economy is a regenerative system in which resource input and waste, emission, and energy leakage are minimized by slowing, closing, and narrowing energy and material loops. This can be achieved through long-lasting design, maintenance, repair, reuse, remanufacturing, refurbishing, and closed recycling. In a Circular Economy the value of products and materials is maintained for as long as possible. Waste and resource use is minimized, and when a product reaches the end of its life, it is used again for energy recovery. Bio-economy is the biological engine of the Circular Economy, not just an integral part of it.

\section{Expectations and prospects for Bio-economy}

Bio-economy is not only important because of its potential to contribute to the welfare of nations, but also to replace fossil fuels in energy production, transport and chemical industries. Bio-economy is expected to play a catalytic role in responding to these challenges and achieving a low carbon economy.

At a time when there is pressure to meet the Paris climate commitments (11) Bio-economy offers:

(I) Health and environmental protection: (a) a viable solution to substituting the petrochemical-based economy, i.e., find new resources and (b) capacity reduction of up to 2.5 billion tonnes of $\mathrm{CO}_{2}$ per year. (II) Economic benefits: (a) New job positions and (b) Creating wealth. (III) Scientific Benefits: (a) New Products and (b) New Processes (12).

Bioeconomy offers great opportunities to both traditional and bio-based industries. It is estimated that Research, Development and Innovation associated with the Bio-economy strategy under the EU Horizon 2020 programme can generate about 130,000 jobs and 45 billion $€$ in added value in Bio-economy sectors by $2025(13,14)$.

Biomass can be derived through various renewable resources. Its use is primarily for food, then for feed and finally for energy, fuels and chemical feedstock production. Hence, the waste from the various biomass types is the most suitable raw material for processing via various methods. Fig. 1 summarizes the origin of various waste-based resources with a strong potential to recover material, fuels and energy.

There are various conversion technologies that can convert biomass resources into a variety of products for food, feed, chemicals and renewable energy (fuels, heat and power). The choice of the conversion technology depends on many factors including the quantity of biomass feedstock, the requested energy form, economic condition, environmental standards and project specific factors. The general conversion processes are shown in Fig. 2.

Biotechnology holds a prominent place regarding technological ways to process biomass as shown in Fig. 2; biotechnology plays an important role in the effective exploitation of biomass. According to the OECD (15) biotechnology is defined as "the application of science and technology to living organisms, 


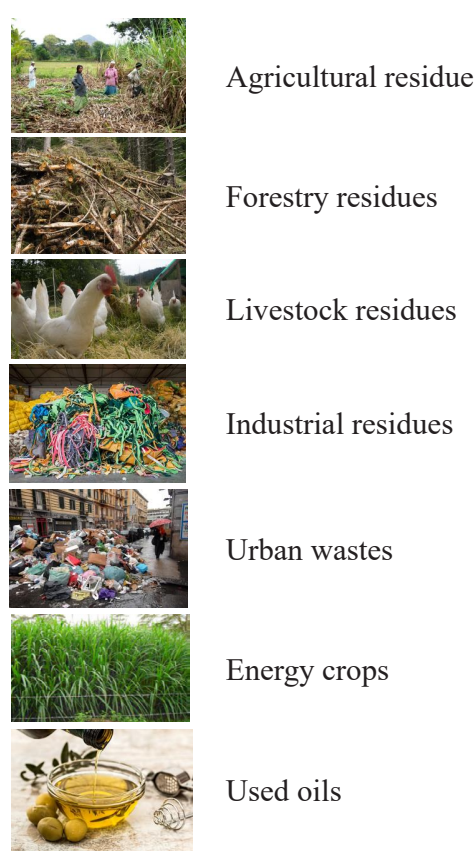

\section{Materials, Fuels and Energy}

Figure 1. Waste-based resources with added value within the Bio-economy concept.

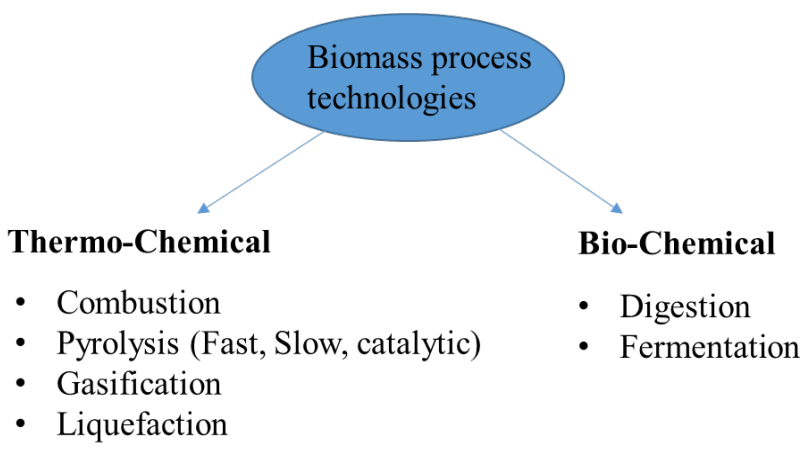

Figure 2. Two major technological means to process biomass: traditional themochemical and bio-chemical.

as well as parts, products and models thereof, to alter living or non-living materials for the production of knowledge, goods and services". The significant progress made in recent years in biotechnology as well as in the other relevant scientific disciplines is an indicator that there is the necessary technical background, however, the realization of Bio-economy and its development is a long lasting process.

\section{Bio-economy in Greece National strategies}

By the beginning of 2018 more than 50 countries worldwide and half a dozen regions officially support Bio-economy via dedicated programmes, strategies, action plans, roadmaps, closely related political programmatic and/or strategic activities. Countries have already developed Bio-economy strategies which, however, differ sometimes considerably in range and content focus. (Global Bio-economy summit 2018 (16).

In the past two years, seven more countries adopted dedicat- ed Bio-economy policy strategies, mostly in Europe. In many countries, sub-regional Bio-economy strategies and policies have been developed in order to exploit local advantages (17).

Greece does not have a specific National strategy on the Bio-economy yet, although the Greek government assigns a high priority to resource efficiency as well as energy-efficient and low carbon investments (18). Nevertheless, the governmental initiatives to date are occasional and disperse.

\section{Greek governmental bodies' activities relevant to Bio-economy and actions}

The main governmental body implementing Bio-economy policies is the Ministry of Environment and Energy (YPEN) which launched the $1^{\text {st }}$ National Strategy for the Circular Economy in the $25^{\text {th }}$ of May 2018 for public consultation. In addition, the "Strategic plan for the development of research, technology and innovation under the National Strategic Reference Framework (NSRF) 200713" (19) aims to restructure the Greek economy, gearing it towards high value added products and services, and achieve the transition to a knowledge based economy and society.

Relevant policy documents and activities in that respect include: (a) The Green Growth Strategic Action Programme (2010-2015) instruments which provide opportunities for industrial biotechnology centers to set up green public procurement and grant green businesses easier access to capital. Solutions for waste management, including waste re-use, are particularly fostered (20); (b) the National renewable energy action plan (2010) - in accordance with the EU's 20\% renewable energy target by 2020 (16) and (c) Law 4414/2016 that drafts the national strategy for protection against the effects of climate change and provides a new Support Scheme for power plants from renewable energy sources and cogeneration of high performance electricity and heat (21). 
Table 1. A compilation of currently active institutions in Bio-economy and Bio-economy related issues

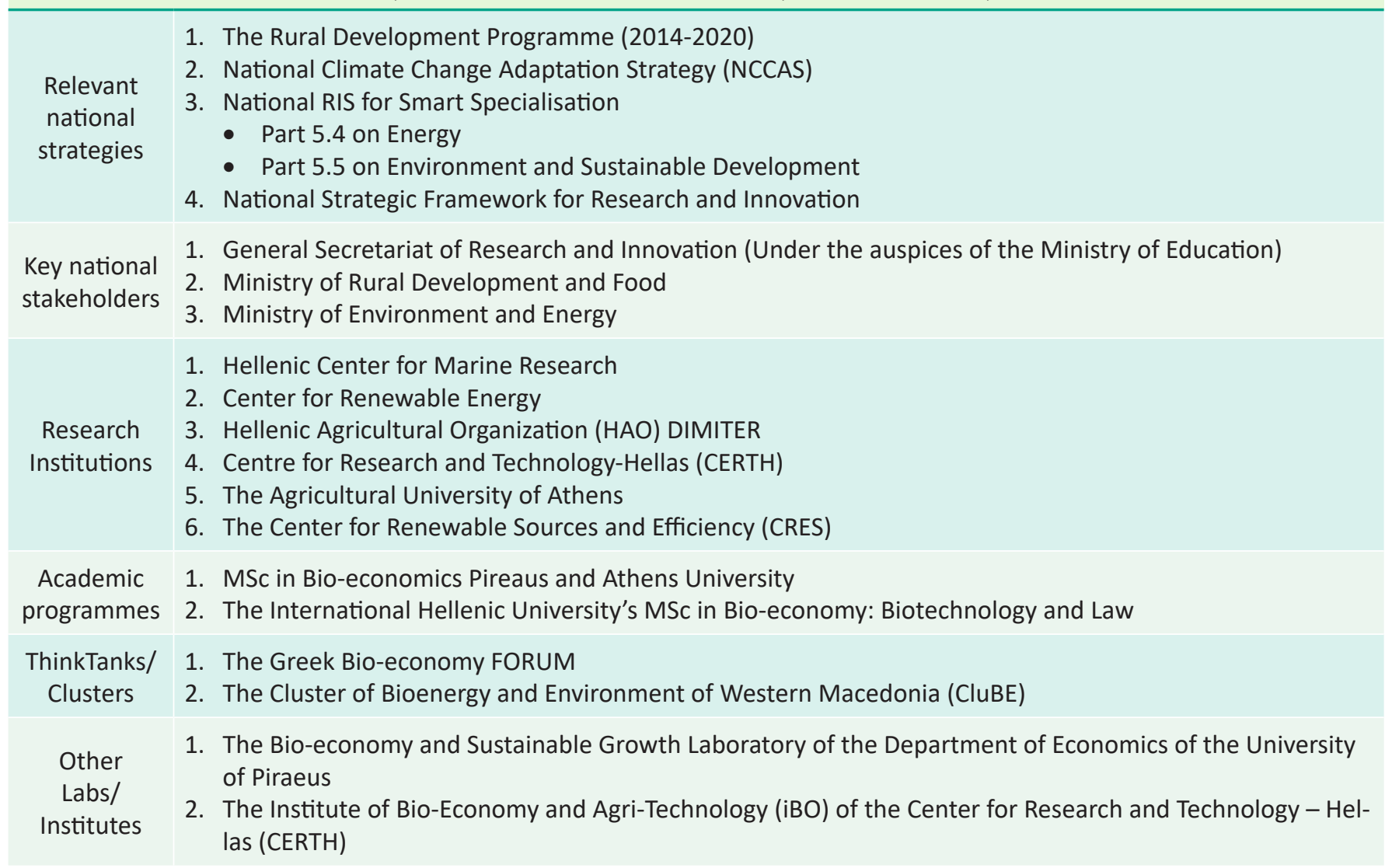

Additionally, the Ministry of Environment and Energy has prepared a list of products and services that are environmentally friendly. It will be available on the Internet to public authorities so that they can identify 'green' products, services and suppliers (22). Public and semi-public authorities have a significant purchasing power and aspire to influence production and consumption patterns, while a significant demand from public services for greener goods can create and expand markets for environmentally friendly products and services.

In 2014 the Greek Government established the General Secretariat for Waste Management Coordination (Government Gazette 9/A '/10.1.2014), with the responsibility to oversee and coordinate the work of the Ministry of the Internal Affairs, Ministry of the Environment, Ministry of Energy and Climate Change and Ministry of the Development and Competitiveness on the issue of waste management. Its responsibilities also include convening coordination meetings, promoting the national strategy and ensuring compliance with the rules and principles of European and national environmental legislation on public procurement, as well as facilitating the support of public and private bodies in the licensing procedures (23).

The National Waste Management Plan was established in 2015 (24). In January 2016, the National Hazardous Waste Management Plan was also established (Government Gazette B 4326/2016) (25). Finally, in 2017 the activation of Regional Waste Management Plans (PECA) for the various regions of the country occured (26).
The aim of the above actions is to integrate and rationalize waste management converting it to a resource in order to reduce the impact on the environment and human health, as well as a positive contribution to economic and social development.

Forest management: The first road map for forests in Greece was announced in 18 April 2018 during the first meeting of the Special Standing Committee on the Protection of the Environment of the Hellenic Parliament, while the public consultation on the National Forest Strategy was launched in 11 May 2018 (27).

This is a significant development for the country since $51 \%$ of the area of Greece is covered by forests and other wooded land (Eurostat 2005). Of the 65,000 square kilometers covered by forest areas in Greece, $53 \%$ is available for timber production (28). National Bioeconomy strategies are summarized in Table 1 .

\section{Bio-economy in Greece at Municipal and Regional level}

Several municipalities have developed initiatives to recycle and exploit biomass. For example the Municipality of Kalamata has created "green spots" where pruning and gardening waste can be deposited. The purpose is the composting of wooden chips for use in the parks and the flower beds of the Municipality of Kalamata.

Crete has started to link Bio-economy development with their Research and Innovation Strategies for Smart Specialization (RIS3) (29). 
Thessaly is a region in Greece that covers 4.7 million $\mathrm{m}^{2}$ of agricultural land and it hosts 5\% of the overall Greek biomass energy stations (2.2 MW) with annual energy potential estimated at 27,000,000 GJ (Bio-economy regions in Europe, 2017). Table 1 presents a compilation of currently active institutions in Greece in Bio-economy and Bio-economy related issues.

Western Macedonia is aiming at eventually substituting lignite with Renewable Energy Sources (RES) for energy production (both electricity and heat) and bioenergy may provide an important part of this energy. In general, Bio-economy can become one of the decisive factors and major pillars for the Post-lignite era in Western Macedonia.

\section{Bio-economy education in Greece}

European education institutions have started to recognize the necessity to educate young scientist in Bio-economy since there is an urgent demand on highly qualified labour force. In Greece there are two postgraduate programs currently running. The newly established MSc in Bio-economics is an interdisciplinary program developed from a partnership of two leading Universities in the country, the University of Piraeus and the National and Kapodistrian University of Athens (30). In Thessalloniki a web-based MSc in Bio-economy Law, Regulation and Management is offered by the International Hellenic University. No relevant Bachelor degree exists so far, as in most European countries (31).

\section{Other initiatives and clusters \\ The Greek Bio-economy Forum}

The Greek Bio-economy Forum is a platform where individuals interested in Bio-economy and Circular Economy come together. The forum operates as a think tank and offers individuals and stakeholders the opportunity to meet, share and network with each other. The vision of the forum is to raise awareness about the Bio-economy \& Circular Economy and promote transfer of know-how and experience in the EU and world-wide (32).

\section{The Cluster of Bioenergy and Environment of Western} Macedonia (CluBE)

The Cluster of Bioenergy and Environment of Western Macedonia (CluBE) is a non-profit company established among local actors and stakeholders of the Region of Western Macedonia. CluBE is developing R\&D and business activities in the fields of bioenergy and environment, in order to reinforce green economy in the region and the neighbouring area (33).

The Bio-economy and Sustainable Growth Laboratory of the Department of Economics at the University of Piraeus

The aim of the Bio-economy and Sustainable Growth Laboratory is twofold: to promote and support academic knowledge and to develop synergies with public and private companies, international organizations, multinational corporations and consultancy firms involved in Bio-economy sectors (biomed- icine, agriculture, food industry, fishing, chemical industry, pharmaceuticals, cosmetics, clothing, etc.). The Laboratory aims at complementing research and educational goals for the need of Bio-economy. At the same time, it aims at constituting a valid scientific agency for incorporating the Bio-economy in the Greek economic growth model. In close cooperation with European Union agents and international institutes and organizations, it wishes to contribute to mentality change in terms of research and development policy, to optimum cooperation and coordination among stakeholders and to promote knowledge as the primary economic factor (34).

\section{The Institute of Bio-economy and Agri-Technology (iBO)}

The Institute of Bio-economy and Agri-Technology (iBO), a non-profit research and technological development organization, constitutes one of the five Institutes of the Center for Research and Technology - Hellas (CERTH) administered by the Ministry of Education, Religions Affairs and Long Life Learning since 2013 (35).

\section{The Center for Renewable Sources and Efficiency (CRES)}

The National Agency for Renewable Energy Sources and their rational use for Energy Saving, CRES (KAPE in Greek), was founded in September 1987 and its main purpose is the promotion of renewable energy applications at national and international level. Renewable energy applications hold a prominent role in Bioeconomy. In particular, biomass can replace a variety of fossil and mineral resources in the economy. This could contribute to climate mitigation and resource efficiency; growth, jobs and energy security. $(36,37)$.

\section{State research centers relative to Bio-economy}

Five additional research centers founded by the Greek state and their activities are closely related to Bio-economy: (a) Hellenic Center for Marine Research (37); (b) Center for Renewable Energy Sources (38); (c) Hellenic Agricultural Organization (HAO) DIMITER (39); (d) Centre for Research and Technology-Hellas (CERTH) (40) and (e) the Agricultural University of Athens (41).

\section{Key national stakeholders}

Governmental bodies which are heavily involved in Bio-economy related issues are: (a) the General Secretariat of Research and Innovation (Under the auspices of the Ministry of Education) (42); (b) Ministry of Rural Development and Food (43); (d) Ministry of Environment and Energy (44).

\section{Greek Bio-economy in numbers}

The Bio-economy sector today in Greece registers a turnover of about 27 billion $€$ and about 0.5 million employers (45). About $80 \%$ of their activities are directly or indirectly related to the agricultural sector. Respectively, the turnover of the EU is around 2 trillion $€(20 \%$ arising from non-food \& agriculture industries) and 17 million jobs have been created (8.5\% of the EU workforces). 
A shift towards a bio-based economy will reduce the dependency on fossil resources for energy, fuels and chemicals and, subsequently, greenhouse gases (GHG) emission are expected to mitigate (46). Greece will have to mitigate GHG emissions by $16 \%$ by 2030 using as reference year 2005 (47). A key point to achieve this is via effective management of our renewable resources and wastes (48).

\section{Agriculture and Bio-economy in Greece}

Agriculture is a significant sector in the Greek economy and it contributes $4.1 \%$ to the Greek Gross Domestic Product (GDP) accounting for $70 \%$ of agricultural products and $30 \%$ of animal product $(49,50,51)$.

Agricultural waste biomass is an excellent feedstock for the production of fuels and chemicals (52). Although only a small part of the available feedstock is exploited in Greece, so far, the renewable energy industry directly employs more than 25,000 rural families today, or about 100,000 rural residents, as well as a large number of relevant activities like, agronomists, transport companies, oil seed factories etc. (53).

The animal waste is characterized by a high organic and inorganic load, however its content in pathogenic microorganisms is very high. The uncontrolled disposal of these wastes has a significant effect in the environment and humans. Therefore with proper management, animal waste may be considered as a source of energy. Table 2 below summarizes the current livestock potential in Greece.

\section{Marine biomass}

Greece has a particularly high fish consumption per person, reaching $19.6 \mathrm{~kg} /$ year, of which $66 \%$ is imported, $22 \%$ of domestic aquaculture products and $12 \%$ of domestic fishery products (56). In Europe, the average consumption per person is $22.9 \mathrm{~kg}$ /year while the world average is $19.2 \mathrm{~kg} /$ year (57).

According to an ELSTAT survey (September 2017), the production volume of fishing and aquaculture reached 197,704.7 tons in 2016, bringing an income 781.3 million $€$. (48) Greece has the largest fishing fleet in the EU (15,188 vessels out of a total of 83,792 within EU). The vast majority (95.1\%) are small or very small vessels operating with stationary gears in the coastal zone (only $1.6 \%$ are purse seiners and $1.7 \%$ are trawlers) (58).
The processing of fish creates up to $70 \%$ liquid and solid waste while data for pelagic fish show that solid waste resulting from their filleting is $44 \%$ (59). From the above data it is obvious that the amount of waste biomass from the fish, which is very rich in high added value biological components. Adding the amount of waste from the processing of the imported fish it is clear that marine waste based on aquaculture is a significant biomass source.

\section{Municipal waste}

In the European Union (EU), the amount of municipal waste generated per person has been calculated as $480 \mathrm{~kg}$ in 2016 . Overall in the EU in 2016, 30\% of the waste was recycled, $27 \%$ incinerated, 25\% landfilled and 17\% composted (60).

Greece is close to this average value producing approximately $500 \mathrm{~kg}$ of waste per person per year with an annual collection cost of about 1 billion $€$. The majority of the waste is deposited to legal (XYTA) and illegal landfills (totally about $81 \%$ ) while $17 \%$ is recycled and only a $2 \%$ is composted. The average of the EU countries is: recycling 25\% and composting 18\%, and exceptionally $5 \mathrm{EU}$ countries burying less than $1 \%$ of their waste. $(61,62,63)$ Illegal landfills are an economic plague for the country, since only from 2014 until early 2018 Greece paid a fine of 48 million $€$. However, the situation seems to improve according to YPEKA, while in 2014 there were 293 illegal landfills; nowadays only 19 are active in small islands and areas of the Peloponnese, and other 23 are inactive and under under rehabilitation process (64).

To date, 1,070 registered companies participate in the Alternative Management Collective System, which cover the largest share of the Greek market. Despite this progress, there is still a significant shortage of solid waste treatment and disposal facilities. The recycling rate is still at very low levels (65).

\section{Food waste}

In 2017 EU set the target of 50\% reduction in food waste by 2030. According to estimates, the EU produces about 88 million tonnes of food waste per year. This corresponds to $173 \mathrm{Kg}$ per person. For Greece, this figure is set at $80 \mathrm{~kg}$ per person. Farms, manufacturing, construction, catering and households are key areas of food waste throughout the supply chain. How-

Table 2. Theoretical potential of livestock biomass (main organic by-products) in Greece $(54,55)$

\begin{tabular}{|l|c|c|c|c|}
\hline Source & Units & Capacity & Waste (t/y) & Power (MW) \\
\hline Cow farms & 26295 & 755665 (cattle) & 13601970 & 233 \\
\hline Pig farms & 3299 & 147920 (sows) & 2277072 & 36 \\
\hline Poultry farms & 1972 & 33875054 & 813001 & 86 \\
\hline Processing of milk units & 696 & 1175319 & 822723 & 14 \\
\hline Total & & & 17514766 & 369 \\
\hline
\end{tabular}




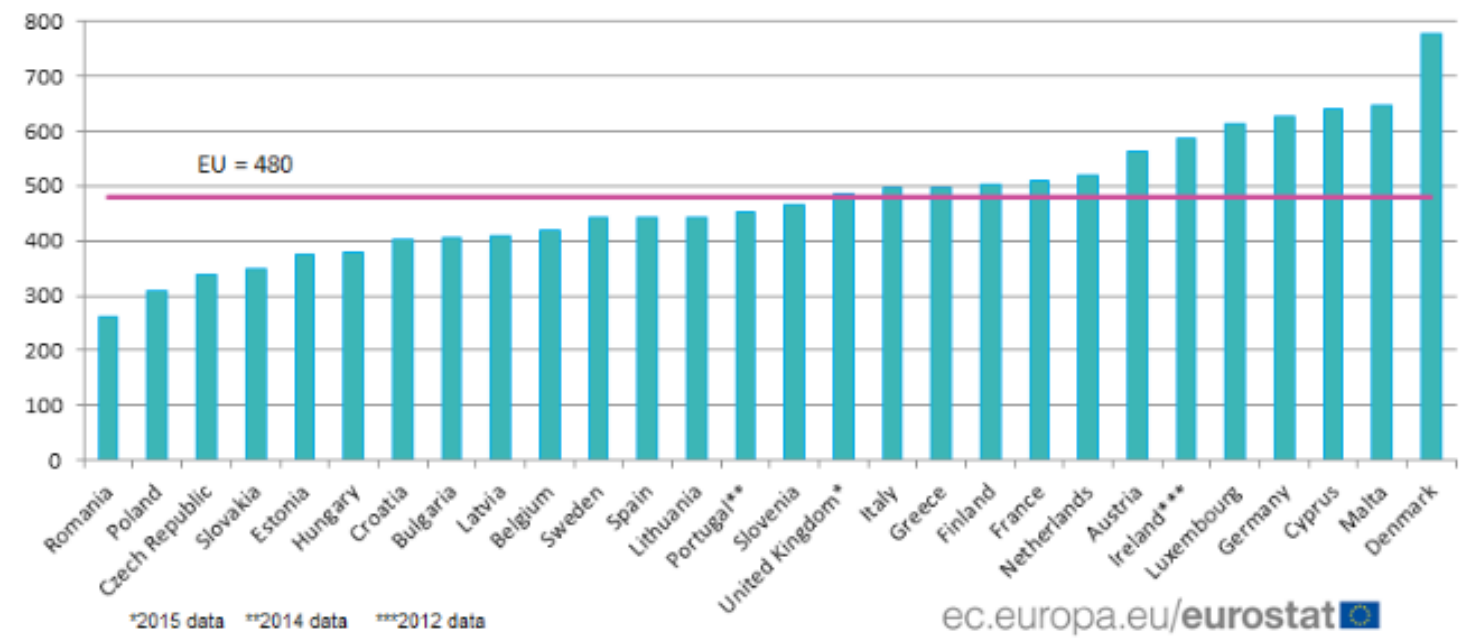

Figure 3. Generation of municipal waste in the EU member states (kg/person) in 2016.

ever, on average and according to estimates, the sectors most contributing to the production of food waste in the EU are $53 \%$ households and 19\% manufacturing (66).

The food industry is highly developed and contributes substantially to the national economy, since it covers $26 \%$ of all domestic industry in Greece (67). Nevertheless, according to current data, there are large quantities of food waste in Greece which are being unexploited in their majority (68). Proper management of domestic fermentable waste can provide a range of value-added products such as biogas (methane, hydrogen etc.), bioethanol, pellets, compost and also contribute to the production of electricity using Microbial Fuel Cells, production of bio-adsorbent material etc. The Municipality of Halandri in Athens, in collaboration with the National Technical University of Athens, is carrying out a project under the European Waste4Think project, HORIZON 2020 to develop the necessary infrastructure for efficient waste management (69).

\section{Biomass conversion products Biofuels/Bioenergy}

Current EU legislation requires its Member States to ensure that renewable energy accounts for at least $10 \%$ of the energy consumed in transport by 2020 (70). Greece has 12 Biodiesel plants located in the main agricultural regions of Greece, where sunflower (and some rapeseed) are grown. Their production capacity is around $130,000 \mathrm{~m}^{3}$ which accounts for the $93 \%$ of the biodiesel consumed in Greece. Biodiesel is almost entirely produced by local feedstock ( $58 \%$ of vegetable oils and the rest from used cooking oils and cotton seed oils).

Moreover, today, according to the ministry of agricultural development and food, 18 biogas units are in full operation in Greece processing agricultural and livestock wastes (71). In 2017, according to DEDDIE SA (Administrator of the Greek Power Distribution Network), 597 biomass power projects with capacity of 369.1 MW were under licensing procedure (15 from the Regulatory Authority for Energy - RAE) (72). The market for biogas production in Greece is open, as the country has a considerable potential of unused organic waste. There are over 20 million tons of organic wastes that could yield more than 350 MWh (73).

However, biofuels consumption in Greece is less than 2\%, because bioethanol is not produced nor imported, thus transportation fuels rely only on biodiesel (CRES 2018).

\section{Chemicals feedstock}

The production of platform chemicals and products through the bio-refinery process of biomass lags behind in Greece as bio-refineries are available either in laboratory or in pilot scale. However recently there are some few initiatives for the establishment of commercial units.

Global energy landscape and potential and barriers for Greece Biomass remains largely unexploited not only in Greece but worldwide. On average, around $14 \%$ of the total biomass is exploited globally (mostly in the field of energy) although 1 ton of biomass is equivalent to about 0.4 tonnes of fossil oil (74).

Biomass residues are also not exploited. It is estimated that waste generation in Greece is $57.983 .751 \mathrm{t} / \mathrm{p}$.a, including agricultural and industrial waste (53\%) and livestock manure $(47 \%)$. However, only $3 \%$ of total biomass is exploited in Greece, mainly as a fuel, while the most widespread practice at least for the management of organic wastes is burning and landfilling. Based on the anaerobic treatment scenario, 21.9 TWh of electricity can be generated from the biomass in Greece, accounting for a 39\% of gross electricity consumption in the country. The exploitation of agricultural and forest residues could compensate for the consumption of 3-4 million tons of petroleum per year, while the exploitation of energy crops could save $30-40 \%$ of the amount of fossil oil consumed annually in the country $(75,76)$.

It is clear that Greece has an important opportunity to ex- 
Table 3. Synopsis of the barriers to the efficient exploitation of biomass and the promotion of Bio-economy in Greece

Fragmentation of agricultural land in many small properties (lot size 4.8 ha against 14,3 in EU-27 and average

1 economic size of farm 9.266,8 $€$ against $25.450,2 €$ in EU-27) that creates lack of reliable transportation network and long-term supply of materials.

2

The high price of raw materials (which initiates biodiesel imports and works inhibitory in the development of business for their further processing).

3 Disorganized and costly supply chain of raw materials

$4 \quad$ Low technical training of farmers ( $32 \%$ have no education)

5 Difficulty in introducing new technologies because of the age of rural population (60\% of farmers over $45 y$ old)

6

Reduction of employment in the primary sector. The family employment covers $85.5 \%$ of total employment in agriculture sector.

7 Lack of control mechanisms for the implementation of existing environmental legislation and penalties on offenders

8 Bureaucratic licensing difficulties

9 Instability of institutional and taxation environment

10 Unstable and inefficient policy, which affects the final price of bioproducts and biofuels/energy.

11 Environmental licensing

12 Lack of appropriate financial mechanisms

13

Lack of public awareness (especially regarding the environmental benefits of energy recovery resulting in strong local resistance to projects)

14

Lack of substantial efforts to create a framework for the marketability of 'green' innovations (69, 70 CRES 2016, 71, 72)

ploit its waste, especially that derived from agricultural crops and livestock farming for the production of fuels and products.

In the energy sector, the total gross consumption in the Greece is estimated at 22,4 Mt. For the period 2011-2035 total new energy investment is expected to reach 28 trillion $€$, corresponding to an average annual investment of approximately 1.2 trillion $€$, globally.

Low participation of RES and other forms of energy shows the high growth potential of the sector in the country through the utilization of its untapped energy reserves.

The barriers to the efficient exploitation of biomass and the promotion of Bio-economy in the country can be summarized in Table 3.

Addressing all of these new challenges requires integration of Bio-economy in the growth model of Greece, changing the attitude on research and development policy, optimal co-operation and co-ordination among the stakeholders, as well as the emergence of knowledge as a dominant economic factor.

\section{Conclusions}

There is evidence that there are significant opportunities in Greece for the development of a wealthy and lucrative economy, based on renewable resources. However, effective growth of Bio-economy in Greece depends on successful cooperation of all stakeholders (state, business, citizens). In this direction, small and medium sized enterprises already play a significant role and together with bigger producers and research partners have started to form businesses and innovations that will develop and bring new bio-based products to the markets. Yet, these ventures will not succeed unless the state finance initiatives and policies through a coordinating and audit role based on appropriate legislative and fiscal frameworks. Considering that every century has a dominant theme that characterizes it, a position is slowly emerging that Bio-economy will probably mark the $21^{\text {st }}$ century. In the belief that we are heading in the right direction to ensure the prosperity and longevity of our planet, let us hope that Bio-economy will be the greatest gift of our age to the future generations.

\section{Conflict of interest statement}

The authors declare that they have no conflict of interest.

\section{References}

1. McNeill JR, Engelke P Mensch und Umwelt im Zeitalter des Anthropozan. In: Iriye A Geschichte der Welt 1945 bis heute. Die globalisierte Welt. C.H. Beck, München, S. 2013, 357-534

2. El-Chichakli B, Braun J von, Lang C, Barben D, Philip J. Five cornerstones for a global Bio-economy. Nature. 2016, 535:221-223

3. UN (2015b) The Global Goals for Sustainable Development. http:// www.globalgoals.org/de/. access: 5. Okt. 2016

4. EC (2012) Innovating for Sustainable Growth: A Bio-economy for Europe. European Commission (EC), Brussels

5. EC (2014) What Next for the European Bio-economy? The latest thinking from the European Bio-economy Panel and the Stand- 
ing Committee on Agricultural Research Strategic Working Group (SCAR). European Commission, Brussels, (http://ec.europa.eu/ research/Bio-economy/pdf/ where-next-for-european-Bio-economy-report-0809102014en.pdf)

6. EC (2015) Closing the Loop - An EU action plan for the Circular Economy. European Commission (EC), Brussels, (http://eur-lex.europa.eu/ legal-content/EN/TXT/?uri=CELEX\%3 A52015DC0614)

7. OECD (2009) The Bio-economy to 2030: Designing a Policy Agenda, Main Findings. Organisation for Economic Cooperation and Development (OECD), Paris, (http://www.oecd.org/futures/ Bio-economy/2030)

8. International Advisory Council of the Global Bio-economy Summit 2015. (2015).

9. Communiqué. Available at http://gbs2015.com/fileadmin/ gbs2015/Downloads/Communique_final.pdf [27.02.18].

10. European Commission, The Knowledge Based Bio-Economy (KBBE) in Europe: Achievements and Challenges Full report (2010).

11. http://www.globalproblems-globalsolutions-files.org/gpgs_files/ pdf/UNF_Bioenergy/UNF_Bioenergy_5.pdf

12. https://ec.europa.eu/clima/policies/international/negotiations/ paris_en)

13. (http://www.Bio-economyalliance.eu/node/98)

14. EC COM 60 (2012)

15. https://ec.europa.eu > European Commission > EIP-AGRI > Focus Groups

16. https://www.oecd-ilibrary.org/.../development-co-operation-report-2014_dcr-2014-en

17. http://gbs2018.com/fileadmin/gbs2018/Downloads/PM_ GBS2018_communique_en.pdf.

18. Bio-economy Part III - Update Report of National Strategies around the World, A report from the German Bio-economy Council, Berlin, April 2018).

19. http://www.industrialbiotech-europe.eu/map/greece/

20. Strategic plan for the development of research, technology and innovation under the NSRF (www.inovasyon.org/pdf/Greece.StrategicPlan.2007-13.pdf) 2007-13

21. http://www.industrialbiotech-europe.eu/map/greece/

22. https://www.taxheaven.gr/laws/law/index/law/769

23. http://www.ypeka.gr/Default.aspx?tabid=749

24. http://www.elinyae.gr/el/lib_file_upload/9a_14.1413540401828. pdf

25. http://www.ypeka.gr/LinkClick.aspx?fileticket=OI1IVu124Jk\%3D\&tabid $=238 \&$ language $=\mathrm{el}-\mathrm{GR}$

26. http://www.ypeka.gr/LinkClick.aspx?fileticket=iHSECSHjFk8\%3D\&tabid $=232$ \&language $=e l-G R$

27. http://ypeka.gr/Default.aspx?tabid=389\&sni[524]=4701\&language $=\mathrm{el}-\mathrm{GR}$

28. https://dasarxeio.com/2018/05/11/56690/

29. http://www.in.gr/2008/10/20/tech/ti-misi-ellada-kalyptoyn-oi-dasikes-ektaseis-symfwna-toylaxiston-me-ti-eurostat/

30. http://ris3.crete.gov.gr/

31. http://Bio-economics.edu.gr/

32. https://www.ihu.edu.gr/

33. https://Bio-economyforum.gr/

34. https://clube.gr

35. www.Bio-economylab.gr

36. https://ieep.eu/news/bioenergy-and-the-bioeconomy-one-and-the-same

37. https://ec.europa.eu (iBO)

38. http://www.cres.gr/cres/pages/parousiasi_cres.html

39. https://www.hcmr.gr

40. www.cres.gr/kape/index_eng.htm

41. www.nagref-her.gr/en

42. https://www.certh.gr/root.en.aspx
43. https://www2.aua.gr/en

44. www.gsrt.gr/central.aspx?sld

45. www.minagric.gr/index.php/el

46. www.ypeka.gr/Default.aspx?tabid=37\&locale=en-US

47. http://ec.europa.eu/eurostat/statistics-explained/index.php/Europe_2020_indicators_-_climate_change_and_energy

48. http://www.voria.gr/article/i-klimatiki-allagi-ke-i-vioikonomiame-tziro-2-tris-evro

49. http://www.unep.or.jp/ietc/Publications/spc/Waste\&ClimateChange/Waste\&ClimateChange.pdf

50. https://www.export.gov/article?id=Greece-Agricultural-Sector

51. https://www.cia.gov/library/publications/the-world-factbook/ fields/2097.html

52. http://www.euro2day.gr/news/economy/article/609978/ti-leneoi-paragogoi-viontizel-gia-tis-times.html

53. http://www.cres.gr/biodiesel/downloads/reports/Greece_National_Report.pdf

54. http://www.euro2day.gr/news/economy/article/609978/ti-leneoi-paragogoi-viontizel-gia-tis-times.html

55. http://buildinggreenexpo.gr/wp-content/uploads/2017/04/1.-\% CE\%96\%CE\%91\%CE\%A6\%CE\%95\%CE\%99\%CE\%A1\%CE\%97\%C E\%A3.pdf

56. https://energypress.gr/news/komision-ta-vasika-empodia-gia-tin-anaptyxi-toy-vioaerioy-stin-ellada

57. https://www.fishforward.eu/wp-content/uploads/2015/06/ WWF_Seafood-and-the-Mediterranean_final.pdf

58. https://iskra.gr

59. http://www.kathimerini.gr/923104/article/epikairothta/ellada/ ekpaideyontas-toys-viwsimoys-alieis-toy-mellontos

60. http://www1.aegean.gr/environment/eda/Envirohelp/greece/ processes/documents/Fish_filleting_preserving.pdf

61. Eurostat $2018 \mathrm{http}: / /$ ec.europa.eu/eurostat/en/web/products-eurostat-news/-/DDN-20180123-1

62. http://www.wwf.gr/images/pdfs/fact_sheet_sterea_apovlita.pdf

63. http://www.agroenergy.gr/categories

64. http://www.naturanrg.gr/katastasi-skoupidia-ellada/

65. http://www.amna.gr/ota/article/236302/To-2018-teleionei-endechomenos-to-problima-tis-Ellada-me-tis-paranomes-chomateres-)

66. http://www.wwf.gr/images/pdfs/fact_sheet_sterea_apovlita.pdf

67. http://www.europarl.europa.eu/news/el/headlines/society/20170505ST073528/graphema-aporrimmata-trophimon-sten-ee

68. Abeliotis et al., (2016): https://www.ncbi.nlm.nih.gov/pubmed $/ 27895283$

69. http://www.sevipa.gr/blog/iobe-e-biomechania-trophimonkai-poton-echei-te-megalytere-symbole-ston-tomea-tes-metapoieses

70. http://www.halandri.gr/Default.aspx?lang=el-GR\&page=327\&ne wsid $=5544$

71. https://www.lawspot.gr/nomika-nea/ekatommyria-tonoi-trofimon-kataligoyn-sta-skoypidia-kathe-hrono-infographics

72. http://www.ebb-eu.org/EBBpressreleases/PR_Biodiesel_save_ CO2\%20emissions_12May.pdf

73. http://www.minagric.gr/images/stories/docs/agrotis/zoika_ypoproionta/tomeasVI_030518.pdf

74. http://www.hellabiom.gr/wp-content

75. CRES: http://www.ypaithros.gr/

76. https://www.aocs.org/stay-informed/read-inform/featured-articles/oil-in-biomass-a-step-change-for-bioenergy-productionapril-2012

77. http://www.ecotimes.gr

78. http://www.cres.gr/energy-saving/images/pdf/biomass_guide. pdf) 